\title{
Reform of translation teaching mode of College English Test Band 4(CET-4) \\ -- in the perspective of micro curriculum and flipped classroom
}

\author{
Qin Guiying \\ School of Foreign Languages, Tianhe College of Guangdong Polytechnic Normal University, \\ Guangzhou510000, China. \\ 865803295@qq.com
}

Key words: College English; education; CET-4; translation; teaching reform

\begin{abstract}
English teaching has always been the focus of education, Chinese College English Test Band 4(CET-4) is an important benchmark to test the college students' English proficiency in China. In recent years, CET-4 and CET-6 exam questions were drastically changed, test questions of CET-4 and CET-6 are basically the same after adjustment, cloze test is canceled, translation question is changed by the sentence translation into postgraduate entrance examination with the same whole translation, and the scores are improved by15 points. CET-4 translation questions position is highlighted, in the translation sector, LV sentence translation from English to Chinese adjust paragraph translation from English to Chinese. Translation content relates to China's historical, cultural, economic and social development, the difficulty is increased. However, in view of the translation of CET-4 teaching system is still not perfect, teaching method and curriculum is not reasonable and other problems, it needs for examination reform of translation teaching models of CET-4.On the basis of the perspective of micro curriculum and flipped classroom, the reform of translation teaching is taken to promote the English application ability, to achieve quality education. Micro classroom is short and pithy, it pays attention to the practice teaching and teaching ability, in perspective of micro classroom teaching, a new mode of university English translation teaching mode is developed, and provides a new teaching model for reference of CET-4 translation.
\end{abstract}

\section{Introduction}

English teaching has always been the focus of education discipline, because the area is wide, a large number of students learn English, especially English is a basic subject in the College English teaching system, along with the global integration of economic development and reform and opening up unceasingly thorough, social requirements are more and more high on English teaching culture mode and the cultivation of practice training. The requirement of English teaching mode is higher and higher, and the advanced teaching method plays an important role in improving the ability of English teaching. College English teaching is training students to use English knowledge to practice, learning and scientific research and social exchange, it is a foundation course. In China, the College English Test Band 4(CET-4) is an important criterion for testing Chinese college students' English master level and qualified or not. The CET-4 is a national education examination, which is presided over by the Higher Education Department of the Ministry of education. The main object of the examination is the undergraduate students or graduate students in the college education according to the syllabus of the education ${ }^{[1-3]}$. The purpose of the CET- 4 is to promote the implementation of College English teaching syllabus, to make an objective and accurate measurement of College Students' English proficiency, and to improve the teaching quality of College English courses. In this paper, the CET-4 translation teaching reform is researched in focus. Recently, CET-4 and CET-6 exam questions were drastically changed, test questions of CET-4 and CET-6 are basically the same after adjustment, cloze test is canceled, translation question is changed by the sentence translation into postgraduate entrance examination with the same whole translation, and the scores are improved by15 points. The CET-4 translation question makes the adjustment, and the difficulty is increased significantly. The new translation questions of CET-4 have the greatest challenges. In translation part, the sentence translation from English to Chinese 
adjusts paragraph translation from English to Chinese. Translation content relates to China's historical, cultural, economic and social development, the difficulty is increased. The topic will give half of the information, it is now asked the whole paragraph translation, or there is a certain difficulty. Originally students only need to translate the sentence, Whole translation test vocabulary and understanding of the article and sentence structure, grammar, the understanding of a word or phrase once wrong, it may translate the whole they stray from the point. In the traditional CET-4 translation teaching model, students used to under the framework of the language system of training context and translation, the traditional teaching mode is using the student's mother tongue and its cultural background, through the translation, the English and English culture are cited into the teaching.

In the traditional mode of teaching, the quality of CET-4 translation teaching is difficult to obtain real improvement, with improvement of English comprehensive ability and application for college students, in the context, the traditional CET-4 translation teaching model is difficult to meet the teaching reform needs. At the same time, new types of translation exam for students to test proposed new requirements, it puts forward new challenges to the English teachers in the teaching. In order to meet the needs of the development of China's economy and foreign exchange, the CET-4 examination questions made for some new adjustments, CET-4 examination reform of translation teaching models are proposed, the first, we analyze the current non English Major Students' English ability present situation, in perspective of micro courses and flipped classroom, new teaching mode of CET-4 examination if discussed, it can make teachers and students more familiar with the CET-4 translation questions, improve the students' comprehensive ability in using English ${ }^{[4]}$.The CET-4 translation question is a kind of deepened difficult new questions, it is a new adjustment of CET-4, after the reform of the translation of the title, students' vocabulary accumulation, grammar application, text comprehension and translation ability are provided a higher requirements. In micro courses and flipped classroom perspective, put forward strategy of reform and innovation of College English translation teaching pattern, let more peer pay more attention to the teaching of translation in the CET-4, and work together to explore undergraduate public English new translation teaching mode to get new teaching mode, which is the core of the "micro curriculum" and flipped classroom, it has attracted the attention of the whole nation. In the CET-4 translation teaching, in micro courses and the flipped classroom teaching mode are proposed, micro course uphold "pay attention to guide, micro perspective, and focus" philosophy of education, to online learning or mobile learning as a way to explore new teaching methods, improve the students' English application ability and practice level ${ }^{[5,6]}$.

\section{Characteristics and present situation of translation teaching in CET-4}

\subsection{Characteristics of CET-4 translation teaching}

English course is a basic course that aims to cultivate college students' theoretical knowledge and practical ability, practical ability is a kind of application ability, it is a skill that students must grasp in practice. CET-4 translation teaching has its own characteristics, CET-4 translation skills in College English learning has irreplaceable role, in English teaching, to make students master the practical skills and teaching method is particularly important. With more emphasis on College English teaching reform of higher education, the requirement of English teaching mode is also more and more high, it needs to pay attention to students' operation and practical application ability and English teachers face a difficult problem. The CET-4 translation topic is an important benchmark of College English teaching reform. Firstly, it analyzes the characteristics of CET-4 translation teaching.

(1) The Time character is more obvious. CET-4 translation content close to the frontier of the historical, cultural, economic and social development, the biggest characteristic of the subject of English is frequently updated content. Basic articles are British and American English learning content based, it is to the limitation of particularly strong are the latest article. In the translation teaching of CET-4, it is also based on these new articles, which is more obvious to the characteristics of the times in the teaching of English translation. It can guide students learning of 
newspapers in simple words, and gradually in-depth study more difficult vocabulary, because of English teaching content updates faster, the translation of English four levels of tests continue to push into new, thus requiring appropriate classroom teaching need through the micro courses and flipped classroom teaching, give the translation teaching of CET-4 the latest and most timely content in English translation teaching. In the teaching of translation in the CET-4, in micro courses and flipped classroom from the perspective of, put forward strategy of reform and innovation of College English translation teaching mode, combined with English classroom teaching in the new content, English teachers need to carefully study materials, a lot of access to domestic and foreign books, newspapers and Periodicals Collected at home and abroad the latest research achievements and development trends, and focusing on the translation teaching of CET-4.

(2)The evaluation system of CET-4 translation teaching is developing, and the teaching methods of College English translation teaching should follow the change of the educational system reform. With the deepening of the reform of CET-4 translation teaching, the evaluation mechanism of College English translation teaching is also in constant development. Master according to student's English level, combined with the CET-4 of translation teaching reform direction, analyzes the reform of CET-4 of translation teaching in classroom teaching, the CET-4 of translation teaching contents and teaching methods were teaching reform strategy analysis. In the four translation teaching of College English, the use of micro curriculum and flipped classroom, for the teaching content, and the choice of the use of classroom teaching, expand the student's thinking space. In the class, the students can upload as much new English knowledge as possible, including English vocabulary knowledge, English background knowledge and English culture knowledge. The micro course education is used, in the flipped classroom from the perspective, through optimizing the allocation of teaching resources, improve the interest of CET-4 of translation teaching, the multimedia teaching is developed with micro classroom teaching, the quality and efficiency of classroom English teaching are improved.

(3) The practical and practical applicability of the CET-4 translation are strong, the teaching methods in College English translation teaching method needs to highlight the practical features. English as a language, English translation is an important manifestation of practical English, through the reform of the CET-4s of translation teaching, the English practice and practical in the application of master and sublimation. English is one of the most applied subjects. In English teaching, it needs to change the past that simply to teach the language teaching and language practice, but to combine the knowledge and language skills training, eventually make students not only learn professional knowledge and to improve the level of foreign language. In the CET-4 translation teaching, the focus is reflected characteristics of practical, in the CET-4 translation teaching, to change the past cramming education theory means, with listening, speaking, reading and writing, improve the practicability of translation teaching, allows students and teachers to fully contact with authentic language materials, participate in real language communication activities, in English communication and application of master its skills.

\subsection{Current situation of translation teaching in CET-4}

CET-4 translation teaching is an important subject, and it has important significance to improve the level of basic English knowledge. Its basic shows that it teaches the basic knowledge of English grammar and vocabulary. The cultivation of English reading and the habit of thinking in English is obtained. The CET-4 translation teaching still exist in the teaching efficiency is not high, discipline characteristic and the teaching goal is not clear, according to the problems existing in the CET-4 translation teaching to carry on the analysis, the teaching content and teaching method, existing problems teaching reform strategy analysis, to improve the level of English Teaching. The current problems of College English translation teaching are reflected in the following aspects:

Firstly, the current CET-4 translation teaching content collocation and curriculum system is not perfect. The CET-4 translation teaching is more oriented to the purpose of teaching to the test, to English education for all-around development in-depth level is not high, but restricted the promotion of CET-4 scores. Current CET-4 translation teaching content and system of system integrity and requirements is still not up to standard, teaching contents and methods need to be 
further optimized, as to improve the efficiency and level of the CET-4 translation teaching.

Secondly, the strength of the allocation of teachers is not enough, the English quality of teaching is not enough attention. CET-4 translation questions on students' knowledge, ability, experience and other comprehensive quality request is higher. However, in University Public English teaching, education management department of English teaching put little effort, uneven allocation of teachers of the CET-4 translation teaching, CET-4 translation teaching configuration exist unreasonable structure and ability is low, resulting in the classroom teaching efficiency is not high.

Thirdly, CET-4 translation teaching resources allocation is not reasonable, the teaching method is single. Combined with the multimedia teaching mode and flipped classroom teaching methods, the CET-4 teaching reform is taken, the CET-4 levels of translation teaching of audio-visual and multimedia teaching into is not deep enough, as English teaching more emphasis on reading comprehension and vocabulary memory, English ability is not high enough, affected the efficiency of classroom teaching.

\section{Study of teaching method of CET-4 translation teaching}

CET-4 of examination reform of translation teaching models is researched based on micro courses and flipped classroom perspective, micro courses and flipped classroom is the hottest new teaching mode, using the micro courses and flipped classroom learning methods for English learning has high value. I the micro courses and flipped classroom teaching mode, CET-4 translation teaching method has changed, to explore the teaching mode of CET-4 translation and course content, we can get deeper understanding, and improve the quality of teaching. At present, the teaching method of College English translation teaching based on micro curriculum is mainly based on heuristic education, multimedia education, feedback law education and flipped classroom education, etc.. Respectively described as follows:

(1) Heuristic education. Heuristic teaching is the most commonly used teaching method, not only in English teaching, the teaching of other subjects also uses this method. Heuristic teaching method, also called open teaching method. The main content is to mine the development of the way of thinking, rich imagination, and training for students to carry out creative thinking. The opening teaching method is used for the cultivation of English thinking and English ability. In the course of the teaching of translation teaching in CET-4, teachers can take the method of probing and questioning, and the students' interest, and strengthen the students' thinking ability. Heuristic methods used in classroom teaching. Step by step guide students master should essentials and contents of English learning, to pre set problems for students to prepare to find information, and in class guide students to solve those problems, lecture should always pay attention to the students' responses, in order to adjust the speed of lectures and method, for their sake, to consider student's point of view, the proposed to allow students according to their abilities and can cause resonance.

(2) Multimedia teaching. Multimedia teaching needs to use the modern teaching tools to implement teaching activities. It common contains slides, videos, projectors, recording pens, computers and other modern electronic equipments. Teachers can put the background about the Anglo American countries made slides, video to the students, the best combination of the characteristics of students to add animation elements we in teaching use this approach us video playback, a brief introduction of U.S. geography, history, customs and social life, lets the student obtain the sense of beauty in the wonderful film, and better learning English.

(3) Feedback method, also called the discussion method. Feedback method and the past teachers only responsible for the classroom, the feedback law requires teachers to pay more attention to the class and students, this is a breakthrough and innovation in teaching methods. Teachers in the spare time to organize the students open forum, students listen to the valuable advice, students according to their own experience freely. It is pointed out that the teachers teaching the success and shortcomings, and in the future how to learn English and communicating with the teachers, to reach a mutually satisfactory results. You can also use the questionnaire method to listen to the views of students. Specific operation is the format and content of the questionnaire designed 
by the teachers, and then organize the students to fill in according to the actual situation, and then by the teacher to recover, collate and analyze, finally through the analysis to draw the conclusion.

(4) Flipped classroom teaching method. In the flipped classroom teaching, the use of video software to record PPT and attach to explain the sound, the teaching practice of CET-4 translation course. Based on the teaching practice of the four translation course in College English, the reform of classroom teaching is carried out. CET-4 translation teaching models is reformed based on micro courses and flipped classroom perspective, completed in a short period of time, the new knowledge learning, teachers in the teaching process, flipped classroom multimedia course design, the effect evaluation mechanism, in flipped classroom of CET-4translation teaching, teacher's role from the knowledge transfer transformation for students learning facilitator, organizer, participant, change from teacher centered, monopolize classroom situation, lets the student in the process of learning and using English gradually mastering learning strategies, promoting the deepening of teaching reform of university English four levels of translation.

\section{Application and practice of translation teaching reform in CET-4}

In view of the problems existing in CET-4 translation teaching, according to student's master English level, combined with the direction of the reform of CET-4, from the perspective of optimizing the allocation of teaching resources, the development of CET-4 translation teaching interest and the development of multimedia teaching and micro teaching and other, to analyze CET-4 translation teaching reform strategy, under the flipped classroom, micro courses, the reform of teaching mode is mainly shown as following aspects:

(1)In view of the current CET-4 translation study direction, the flexible processing teaching material, fully prepares for the lesson, sets up the brand-new teaching idea. The concept of the new curriculum stressed that the teaching process is process of teachers' "teaching with the text", instead of "teaching the textbook". Teaching materials are only a kind of teaching tool, we can't rely on the teaching material too much in the course of teaching. Combined with the practice of CET-4 translation, especially in connection with the actual learning situation of students, the content of teaching materials will be re created, so that teaching is more targeted and practical. In short, teachers in teaching should follow the "Curriculum", the activation of teaching materials, from the student's "zone of proximal development", fully prepare lessons, pay attention to details, and effectively improve the effectiveness of classroom teaching.

(2) Rational use of teaching methods, do not blindly from the new. Research a kind of effective university English four levels of translation teaching efficiency optimization strategy, combined with the CET-4translation exam reform direction, analyzes the reform of CET-4 teaching, in the micro process of curriculum design make full use of domestic and foreign design patterns such as David Penrose micro curriculum model, Liang Leming micro course design mode, combined with micro course, new teaching methods construct suitable for CET-4 translation teaching unique micro course design mode. According to the actual situation of teaching and the need to choose the appropriate teaching methods, we cannot blindly pursue the novel teaching methods and ignore the effectiveness of classroom teaching.

(3) Optimization of classroom teaching methods. The main feature of micro teaching is that it has the streaming media player, which can be used in the network streaming media such as video, animation and so on. Three is the teaching time is short. Micro teaching 5-10 minutes is appropriate, especially suitable for CET-4 translation teaching, through micro classroom and classroom flip, slowly to cultivate students' interest in English translation, translation teaching takes micro teaching methods, at least 1-2 minutes, the longest should not be over 20 minutes of teaching time is the most suitable. With the exquisite teaching design, the real and concrete teaching schemes are obtained. With analysis students' behavior and study habits, implementation of quality education, improve the quality of CET-4 translation teaching.

(4) Optimizing the design pattern of CET-4 translation teaching. The design mode of teaching classroom is an important aspect to improve the effectiveness of classroom teaching. Teachers teach and students learn should be realized through language teaching, teachers need to carefully design 
their own classroom discourse, concise and give up discourse hegemony, to be humorous, the sound should be loud, tone, cadence, and the students develop communicative reincarnation. But also requires teachers to seriously study teaching content, analysis of the students needs, make their own words (including questions) have a definite object in view, to ensure that students want to hear, hear, listen to this, so students to resonate with the teacher for interaction.

(5) Cultivate students' Autonomous learning. CET-4 translation teaching can improve students' Comprehensive English quality education as the purpose, through the cultivation of students' autonomous learning ability, in the micro course from the perspective of, in the flipped classroom is to students as the main body of education, and students are the masters of learning. Therefore, in the process of implementing quality education, teachers should pay attention to the cultivation of students' autonomous learning ability, promote students to explore and think in teaching activities, and achieve the best teaching results. To this end, teachers in teaching should be from the following aspects to cultivate the students' self-learning ability: Firstly, the establishment of a harmonious relationship between teachers and students. Teaching practice shows that students love a teacher, joint also love the teacher taught courses, they will actively explore the subject knowledge, it can promote the formation of students' awareness of autonomous learning; Secondly, it is creating a situation, formation, causes the student to be willing to learn. Students are willing to learn, you can take the initiative to explore new knowledge, learning initiative is high; Thirdly, encourage students to boldly questioned, willing to think, independent study. CET-4 translation teaching in the classroom to create a relaxed atmosphere for learning, let students in the learning footloose and fancy free, to enable students to really grasp the initiative in learning, become the master of learning, so that students will actively participate in learning, the main body can give full play to. In a word, by turning the classroom teaching mode, teachers' role change from knowledge transfer to student learning facilitators, organizers, participants, change from teacher centered classroom, monopoly situation, uphold the principle of "value guide, micro start, focus on" philosophy of education, based on the survey and analysis of the teaching object and education environment and discipline characteristics on the synthesis of the existing micro model of curriculum design for CET-4 translation teaching in the new teaching mode, students can gradually master learning strategies in process of the learning and using English, from passive to active learning, optimization model of the CET-4 translation teaching is realized.

\section{Conclusions}

The reform of CET-4 translation teaching is researched in this paper to promote the improvement of English application ability, and improve the quality of teaching. Micro classroom is short and pithy, a new mode of development of CET-4 translation teaching is proposed. In order to improve the level of College English teaching, it provides a new teaching model for reference in micro course and flipped classroom perspective, the reform scheme will glow with new vitality and vigor, and it can fundamentally improve the students' English application practice ability and level.

\section{References}

[1] LIU Xu-dong. On Educational Practice Ability of Normal Students and the Reform of Education and Internship Program[J]. Contemporary Education and Culture, 2011, 3(2): 74-79.

[2] SHI Lei, ZHAO Ping. Media convergence in the context of traditional media news client [J]. News front, 2015,2:50-53.4

[3] ZHANG Jianfeng. Study on the integration of traditional media and new media [J]. Western broadcasting and television, 2015,3:81-82.

[4] ZHANG Anfu. Reform teaching methods to explore research based teaching [J]. Chinese university teaching, 2012 (1): 65-67.

[5] LIN Ying, LI Tong, DU Lei. Research on project driven teaching method of innovative design courses [J]. Computer education, 2015 (9): 72-74.

[6] LU Xing-Hua,CHEN Pinghua. Traffic Prediction Algorithm in Buffer Based on Recurrence Quantification Union Entropy Feature Reconstruction[J]. Computer Science, 2015,42(4):68-71. 